sections in Podolia. The resulting monograph Les brachiopodes gotlandien de la Podolie polonaise, has been described by Shirley as 'a source of inspiration for a generation'; but this referred to the impeccable standard set by his brachiopod descriptions, especially of their internal structures. It was seminal in another way, since it gave details of a marine sequence passing from the Silurian into the Devonian. The area has recently been critical for the international definition of the Silurian/Devonian boundary.

In 1931 he noticed that graptolites were preserved in translucent chalcedony in Tremadocian rocks of the Holy Cross Mountains, and he discovered how easily these could be extracted by dissolution in hydrofluoric acid. This led eventually to the discovery of three new groups of graptoloid, and the discovery of much new detail on the ontogeny of the dendroid graptolites, and also the development of immaculate serial sectioning techniques. It also led to the extension of the techniques to other periods and a corresponding range of contributions on other groups.

The story of the survival of Kozlowski's manuscript for his monograph on Polish Tremadocian graptoloids is a most harrowing tale. His work was completed in 1939 and the bombing of Warsaw imperilled his laboratory, so he moved the typescript, illustrations and most of the specimens to a basement below the Seismological Conservatoire: his institute was destroyed. The Conservatoire was also destoyed, but a month later he was able to enter the basement, but found it sacked, and his material missing. Several months later he found part of his original manuscript in the university ruins, and shortly after, his friend Dr Rozkowski, who was later assassinated, discovered the remainder buried under snow in a courtyard.

At the Warsaw uprising of August 1944 Kozlowski was expelled, but first he hid his manuscript in the central heating system of a private house and, although the house was ruined, he was able to rescue the manuscript in 1945. The originals for his plates were lost, but since he had taken the precaution of sending negatives of these to Paris in 1939 , he was able to publish the monograph in 1949. Immediately, this establshed a new reputation for him in the field of the graptoloids. Particularly important was the detailed case he argued for assigning this important fossil group to the Pterobranchia of the Hemichordata.

After the Second World War he returned to teaching and built up his research school again and until 1960, when he retired, he was Chairman of the Palaeontological Institute of the Polish Academy of Sciences in Warsaw. When the writer visited him in 1962 he was enthusiastically engaged in preparations for the Polish Mongolian expeditions which have led to so many valuable studies under the direction of his former student Professor KielanJaworowska.

The Geological Society of London awarded him the Wollaston Medal in 1961; he was an honorary member of many Polish and international scientific societies, an honorary graduand of the universities of Krakow, Paris and Modena, a member of the Academies of Science of Poland, Czechoslovakia, France and Colombia; he was a Polish Scientific Prize-winner of the first degree.

The most important other monuments to the work of Roman Kozlowski are the two periodicals which he founded, namely, Palaeontologica Polonica of which he edited thirty-four volumes between 1929 and 1976, and Acta Palaeontologica Polonica which he edited from 1956 to 1974 . These record the incredible breadth of research work done largely by himself and his students and research associates, and give an indication of his infectious enthusiasm for all branches of palaeobiology.

Michael House

\section{George Cotzias}

ON June 13, 1977, just 3 days before his 59th birthday George Cotzias died of lung cancer. With his untimely passing the world lost a prominent neurobiological investigator who had made a number of fundamental contributions to the field.

Born in Athens, Greece, the son of a prominent political figure, he fled to the United States in 1941 when his country was occupied during World War II. His medical education which had begun at the University of Athens was continued at Harvard where in 1943 he was awarded the MD degree. Dr Cotzias then served as a house physician on the neurological and medical services of the Massachusetts General Hospital following which he began his career in research at the Rockefeller Institute in New York City. His initial interest centred on renal function but he soon became intrigued with the biological role of trace metals in tissue metabolism particularly in regard to the nervous system.

I remember well my first contact with Dr Cotzias in the 1950s. He was working on the mechani.ms by which enzymes involved in oxidative phosphorylation were activated by manganese and how this might alter central nervous system function. I was organising a symposium on parkinsonism and invited him to discuss his work. Over a three-day period in the Ramapo Mountains of New York I came to know George's innovative and individualistic approach to science; his keen mind, his wit and gregarious yet unimposing nature.

$\mathrm{He}$ was then working at the Brookhaven National Laboratories to which he had moved in 1953 and where laboratory and clinical facilities were made available to him. Gathering a substantial team of investigators around him he began expanding his investigative program with particular interest in the biochemical mechanism underlying extrapyramidal and behavioural disorders. Stimulated by his previous work with manganese, as well as the growing body of information concerning the possible role of monoamines in melanin pigment formation, he was deeply involved in defining its role in Parkinson's disease. Though many were exploring the therapeutic value of monoamines particularly dopa in the treatment of parkinsonism, none approached it with the tenacity and courage of George Cotzias. Where others were constrained by adhering to the usual principles of therapeutics, he felt that the brain mechanisms were unique and required a more adventurous approach. The dramatic effects of reversing the symptoms of parkinsonism by giving large doses of L-dopa which were achieved by the Cotzias's group is undoubtedly one of the major milestones in the treatment of neurological disorders. Not only have literally millions with the disease benefited from its use, but the therapeutic principle has found applicability to other disorders. Despite being hailed by some as a panacea for Parkinsonism, Cotzias was the first to admit that it offered only a prolonged holiday from the symptoms and much more had to be done to effect a cure. Indeed, he devoted the last 10 years of his life to looking for more effective means of overcoming the dopamine deficiency in the brain of parkinsonians.

Dr Cotzias received many honours during his life, among which were the Albert Lasker Award in Clinical Medical Research in 1969, the Borden Award in 1972 and the Oscar B. Hunter Award from the American Society of Clinical Pharmacology and Therapeutics in 1973. His native country recognised his contributions with an Honorary Doctor of Medicine degree from the National and Kapodistrian University in Athens, and in 
appointing him Grand Commander of the Royal Greek Order of the Phoenix and the Archon Actuarius of the Ecumenical Orthodox Patriarchate.

At the time of his death he was Professor of Neurology at the Cornell Medical College, Attending Physician at New York Hospital and a Special Assistant to the President of the Memorial Sloan-Kettering Cancer Center. He had accepted these positions in 1974, moving his laboratories and personnel just prior to becoming ill. Despite this, he continued to be active and involved in a number of new fields of investigation related to the aging process in the nervous system and mechanisms involved in carcinogenesis. Undoubtedly, this work will be carried forward by his colleagues and collaborators, many trained by him over the years. Yet his presence will be sorely missed in the scientific community throughout the world.

Melvin D. Yahr

\section{F. Hickling}

DR C. F. Hickling, CMG, ScD, who died on 14 June at the age of 74 had a unique influence on the development of marine, lake and river fisheries and fish culture over the wide extent of the former British Empire. He was educated at Taunton School and then at St. Catherine's College, Cambridge, to join, in 1927, the staff of the Fisheries Laboratory at Lowestoft. He was a born fisheries naturalist, as keenly interested in the methods of fishing and in the fishermen as in collecting data and interpreting their significance. His prime concern was with the hake fishery, to rise and then fall during this period. It has rightly been said that our knowledge of the biology of that fish owes everything to him. This formed the subject matter of a series of reports largely summarised in his Buckland lectures for 1934 on The Hake and the Hake Fishery.

During the war he was Port Fishery Officer at Milford Haven. In 1945 he was appointed Fisheries Adviser to the Secretary of State for the Colonies. In 1961 , a year before his retirement, he was transfered to the Department of Technical Co-operation. His activities were literally world-wide, on innumerable islands in the Caribbean and Pacific, in East and West Africa, in Malaya, Singapore, Hong Kong and Sarawak. He advised on river fisheries in Nigeria, on those of the great lakes of Central Africa-then on those of the created Lake Kariba-and promoted development of sea fisheries off African and Pacific coasts.

$\mathrm{He}$ was responsible for the organisation of training courses for fisheries officers appointed during this belated period of colonial activity, also for advice on the location and planning of research laboratories notably at Entebbe in Uganda, in Zanzibar, on Lake Nyasa, at Freetown, Sierre Leone and at Singapore. The largest scheme, carried through during the communist troubles, was the Tropical Fish Culture Institute at Malacca of which, there happily accompanied by his wife, Marjory, he was Acting Director in 1957-59. There he succeeded in crossing strains of Tilapia mossambica to produce unisex cultures which grew without the runting that accompanies the early reproductive activities in these fish.

It was a notable experience, as the writer can testify, to accompany Fred on a tour. He moved from the Governor's residence to the humblest fish landing, advising on scientific and commercial policy and then on the fitting of outboard motors to dug-out canoes, on the quality and handling of nets and on preserving and marketing of the catch. He was rightly described as a 'one man FAO'.

$\mathrm{He}$ leaves much of his wide knowledge to posterity in the pages of his books on Tropical Inland Fisheries and Fish Culture. All who knew him remember him with deep affection, so utterly the right man in the right place. We think also of his widow and two sons.

Maurice Yonge

\section{J. A. Robbie}

JAMES ANDREW ROBBIE, FRSE, FGS, died in Edinburgh in his 67th year on 19 May 1977. Born near Laurencekirk he graduated BSc with Honours in Geology at Aberdeen University in 1934. After a short period as Demonstrator in the Geology Department there he was appointed Geologist in the Geological Survey of Great Britain in 1935. He served initially in southern England carrying out geological surveys in the vicinity of Chatham, Bridport and Yeovil. Publication of his work was delayed by the Second World War but eventually appeared as a paper on the Chalk Rock at Winterborne Abbas in his favourite county of Dorset and contributions to the Geological Survey Memoirs on Chatham and Bridport and Yeovil. Although concerned with water supply, mineral resources and airfield construction during the war he was located in London, a period of his life which evoked vivid tales of the blitz and food shortages, the latter being the greater burden for the gourmet.

In 1947 he was transferred to Belfast as part of the team which initiated the Geological Survey of Northern Ireland. On promotion to District Geologist in charge of the Belfast Office in 1959 he was instrumental in establishing the close relationships with central and local government which have resulted in a key role for the Geological Survey in the area. The acme of his geological career came in Northern Ireland with many studies including those of the Mourne Mountain granite as revealed in the Slieve Binnian Tunnel and of the Carboniferous stratigraphy proved by boreholes between Coalisland and Dungannon, published in the Bulletin of the Geological Survey of Great Britain. The scope of his experience and knowledge is demonstrated by his accounts of lithology, stratigraphy and structure of strata of the Dalradian, Silurian, Carboniferous, Triassic, Rhaetic, Liassic, Cretaceous, Tertiary and Pleistocene in memoirs describing the geology of the Dungannon, Ballycastle and Belfast districts.

When promoted to Edinburgh to be Assistant Director in charge of all the activities of the Institute of Geological Sciences in Scotland he was so deeply entrenched in Northern Ireland geology that his model became something of an anathema to the Scots in their analyses of local geology. While involved in the expansion of IGS activities both on land and offshore he played a major role in planning and developing Murchison House, the new headquarters of IGS in Scotland, which was nearing completion as he retired in 1975.

Elected a Fellow of the Royal Society of Edinburgh in 1968 he was appointed Vice President in 1975. He was a Fellow of the Geological Society of London, served as President of the Edinburgh Geological Society from 1971-73, and was elected an Honorary Member of the Belfast Geologists' Society of which he was President twice. In his official capacity he served on the Council of Management of the Macaulay Institute for Soil Research from 1969 until 1975.

A quiet, shy, self-effacing man Jim Robbie shunned the social scene and yet enjoyed nothing more than to meet friends over a glass of his favourite national spirit. He faced his retirement full of plans for remodelling his garden, refurbishing his beloved old car and travelling the world, plans only in the earliest stages of fulfillment when he died.

G. I. Lumsden 